\title{
Hematological differences between patients with different subtypes of sickle cell disease on hydroxyurea treatment
}

\author{
Fabia Neves \\ Osvaldo Alves Menezes Neto \\ Larissa Bueno Polis \\ Sarah Cristina Bassi \\ Denise Menezes Brunetta \\ Ana Cristina Silva-Pinto \\ Ivan Lucena Angulo
}

Hospital das Clínicas da Faculdade de Medicina de Ribeirão Preto, Universidade de São Paulo - USP, Ribeirão Preto, SP, Brazil

Conflict-of-interest disclosure:

The authors declare no competing financial interest

Submitted: 4/8/2012

Accepted: 7/31/2012

Corresponding author:

Ivan Lucena Angulo

Hemocentro - Hospital das Clínicas da

Faculdade de Medicina de Ribeirão Preto da Universidade de São Paulo - HC FMRP USP

R Ten Catão Roxo - 2501, Monte Alegre

14.051-140 Ribeirão Preto, SP, Brazil

ilangulo@uol.com.br

www.rbhh.org or www.scielo.br/rbhh
Objective: Sickle cell anemia and the interaction S/Beta thalassemia differ in hematological values due to microcytosis and hypochromia caused by the thalassemic mutation. The clinical benefit of long-term hydroxyurea treatment is undeniable in sickle cell disease with monitoring of the biological action of the drug being by the complete blood count. The objective of this work is to compare changes in some of the erythrocytic indexes between S/Beta thalassemia and sickle cell anemia patients on long-term hydroxyurea treatment.

Methods: The values of erythrocyte indexes (mean corpuscular volume and mean corpuscular hemoglobin) were compared in a retrospective study of two groups of patients (Sickle cell anemia and S/Beta thalassemia) on hydroxyurea treatment over a mean of six years.

Results: The quantitative values of the two parameters differed between the groups. Increases in mean corpuscular volume and reductions in mean corpuscular hemoglobin delay longer in S/Beta thalassemia patients ( $p$-value $=0.018)$.

Conclusion: Hematological changes are some of the beneficial effects of hydroxyurea in sickle cell disease as cellular hydration increases and the hemoglobin $S$ concentration is reduced. The complete blood count is the best test to monitor changes, but the interpretation of the results in S/Beta thalassemia should be different.

Keywords: Anemia, sickle cell; Hydroxyurea; Hemoglobinopathies; Erythrocyte indices

\section{Introduction}

Silvestroni and Bianco first described the S/Beta thalassemia association in Italy, in $1944^{(1)}$. In Brazil, the first study on clinical, hematological and genetic characteristics of this association was performed in Ribeirão Preto by Zago et al. ${ }^{(2)}$. The hematological data provide elements to differentiate between S/Beta thalassemia and homozygous S (SS) as with $\mathrm{S} /$ Beta thalassemia, patients present microcytosis and hypochromia seen by the low values of mean corpuscular volume (MCV), mean corpuscular hemoglobin $(\mathrm{MCH})$, fetal hemoglobin increase $(\mathrm{Hb} \mathrm{F})$ and hemoglobin $(\mathrm{Hb}) \mathrm{A}_{2}$. The clinical progression is similar, although there are associations with benign mutations of thalassemia. The benefits resulting from treatment with hydroxyurea (HU) in patients with sickle cell disease are undeniable ${ }^{(3)}$ in particular for SS and S/Beta thalassemia individuals. Considering this, its use is highly recommended for patients with poor prognoses, which constitutes most affected individuals. Several studies ${ }^{(4-9)}$ have shown the benefits of $\mathrm{HU}$ in subjects with severe $\left(\beta^{0}\right)$ or less severe $\left(\beta^{+}\right)$thalassemia mutations combined with $\mathrm{Hb} \mathrm{S}$. It remains to be proven whether $\mathrm{HU}$ can be extended to adult carriers of $\mathrm{Hb} \mathrm{SC,} \mathrm{Hb}$ SD associations and others; the results are favorable in children ${ }^{(10)}$.

Studies on S/Beta thalassemia are scarce due to the small number of patients and the reduced candidate group for $\mathrm{HU}$ treatment. The association with Beta thalassemia attenuates some aspects of the disease in some patients and an unfavorable clinical evolution, such as vaso-occlusive crisis (VOC), acute chest syndrome (ACS), several hospitalizations etc., is necessary to prescribe $\mathrm{HU}$. Treatment using $\mathrm{HU}$ in S/Beta thalassemia was tested in Greek patients ${ }^{(4)}$ simultaneously with the Multicenter Study of HU in sickle cell anemia ${ }^{(3)}$. Most of the patients presented clinical improvement and increases in hematological values over the long term. In a later review, effects in children with $\mathrm{S} / \mathrm{B}$ eta thalassemia ${ }^{(5)}$ were observed. Another study found premature hematological alterations $(4 \text { weeks })^{(6)}$, and in a more recent study ${ }^{(7)}$ the hematological response was significant after six months of HU treatment. In Sicily ${ }^{(8)}$, S/Beta thalassemia patients with poor evolution were studied and there was evident clinical improvement with increases in MCV but without increases in $\mathrm{Hb}$ levels and with few significant adverse effects. The largest prospective study on survival in S/Beta thalassemia patients ${ }^{(9)}$ showed a great reduction in clinical complications and increases in survival compared to patients who were not treated with $\mathrm{HU}$, thus consolidating the significant benefits of the drug in this sickle cell syndrome. A prospective study on the action of HU in sickle cell anemia ${ }^{(11)}$ showed early hematological alterations that constitute an easy manner to measure the action of the drug, thus electing the complete blood count as the best test to monitor toxicity and adherence.

Since 1999, sickle cell disease and HU treatment has been studied in Ribeirão Preto, Brazil. The different hematological values in homozygous $\mathrm{S}$ and $\mathrm{S} /$ Beta thalassemia patients led to a 
comparative study of HU response between these two groups, in particular in respect to $\mathrm{MCV}$, which has been used to evaluate the biological action of HU and patient adherence to treatment.

\section{Methods}

A retrospective study was performed of 57 patients with sickle cell disease allocated to two groups: $\mathrm{S} / \mathrm{Beta}^{0}$ and $\mathrm{S} / \mathrm{Beta}^{+}$ thalassemia (S/Beta Group) and homozygous S (sickle cell anemia - SS Group). The diagnoses were made from the results of hemoglobin studies by alkaline $\mathrm{pH}$ electrophoresis and high-performance liquid chromatography and when possible by a familial study, characterizing either homozygous $\mathrm{S}$ (carriers of hemoglobin $\mathrm{S}$ with normal $\mathrm{A}_{2}$ values) or $\mathrm{S} /$ Beta thalassemia (carriers of hemoglobin $\mathrm{S}$ with increased $\mathrm{A}_{2}$ values). All patients took $\mathrm{HU}$ for a period of one to 11 years (mean six years) for several complications of the disease. The hematological indexes, i.e., total hemoglobin, total leukocyte count, neutrophils and platelets, $\mathrm{MCV}$ and the MCH concentration, were closely monitored. The values were checked each month and recorded in the third, sixth and 12th months during HU treatment and a current measurement (July, 2010) after 1 to 11 years. Regular doses of folate were administered and Vitamin B12 was dosed at least once, thus discarding the possibility of other causes of macrocytosis. Although several patients had sporadic erythrocyte transfusions during the study period, the recorded values were not influenced by the transfusions. All the SS and $\mathrm{S} / \mathrm{Beta}^{0}$ thalassemia patients received prophylactic penicillin regularly. The Kruskal-Wallis test was used for the statistical analysis of the paired nonparametric values between the S/Beta thalassemia and SS groups and the Mann Whitney test was used to compare values between the third, sixth and 12th months and current values in relation to the basal measurements. Significance was set for a two-tailed p-value $<0.05$. Total $\mathrm{Hb}$ and $\mathrm{Hb} F$ values, basal and after 12 months of $\mathrm{HU}$ treatment were compared in both groups using the Wilcoxon test of the Prism 5 GraphPad program for Windows (GraphPad Software, Inc. 2012). The paired t-test (Excel v 12.1.1. 2008 for $\mathrm{Mac}$ ) was used to analyze alterations in the $\mathrm{MCV}$ and $\mathrm{MCH}$.

\section{Results}

The S/Beta Group was composed of 11 male and seven female patients with a mean age of $23.8 \pm 8.6$ years (range: $9-43$ years old) and a mean HU dose of $24.7 \pm 5.8 \mathrm{mg} / \mathrm{kg} /$ day. The means and standard deviations of $\mathrm{Hb} \mathrm{F}$ varied from $5.5 \pm 6.22 \%$ (range: $0.1-20.0 \%$ ) before $\mathrm{HU}$ treatment to $21.1 \pm 12.6 \%$ (range: $5.9-42.1 \%)$ after treatment $(\mathrm{p}$-value $=0.0006)$ and total $\mathrm{Hb}$ ranged from $8.6 \pm 1.4 \mathrm{~g} / \mathrm{dL}$ (range: $6.1-11.3 \mathrm{~g} / \mathrm{dL}$ ) before to $9.5 \pm 1.5 \mathrm{~g} / \mathrm{dL}$ (range: $7.1-12.5 \mathrm{~g} / \mathrm{dL}$ ) after 12 months of treatment $(\mathrm{p}$-value $=0.0075)$.

The SS Group had 19 male and 20 female patients with a mean age $26.7 \pm 10.5$ years (range: $11-59$ years old) and average dose of $\mathrm{HU} 24.07 \pm 5.5 \mathrm{mg} / \mathrm{kg} /$ day. The $\mathrm{Hb} \mathrm{F}$ varied from $2.9 \pm 2.1 \%$ (range: $0.5-8.4 \%$ ) before $\mathrm{HU}$ treatment to $21.6 \pm 7.4 \%$ (range: $7.4-34.5 \%)$ after treatment $(\mathrm{p}<0.0001)$ and total hemoglobin varied from $8.4 \pm 1.0 \mathrm{~g} / \mathrm{dL}$ (range: $5.7-10.5 \mathrm{~g} / \mathrm{dL}$ ) before HU treatment to $9.2 \pm 1.5 \mathrm{~g} / \mathrm{dL}$ (range: $6.4-13.6 \mathrm{~g} / \mathrm{dL}$ ) after 12 months of treatment ( $\mathrm{p}$-value $=0.0023$ ).

The indications for HU use were VOC, priapism, severe hemolysis, pulmonary hypertension and ACS for both the S/Beta and SS Groups, besides heart failure and ischemic stroke. The incidence of VOC and ACS was higher, albeit not significantly, in the SS group (t-test, data not shown).

The results for MCV and $\mathrm{MCH}$ concentrations of the groups in the third, sixth, and 12th months and after the follow-up (more than 1 to 11 years) are shown in Tables $1 \& 2$ as absolute values and increases (+) or decreases (-). The mean length of HU treatment was statistically similar for both groups.

Table $1-$ MCV (mean \pm standard deviation) and increases after hydroxyurea treatment in sickle cell disease patients

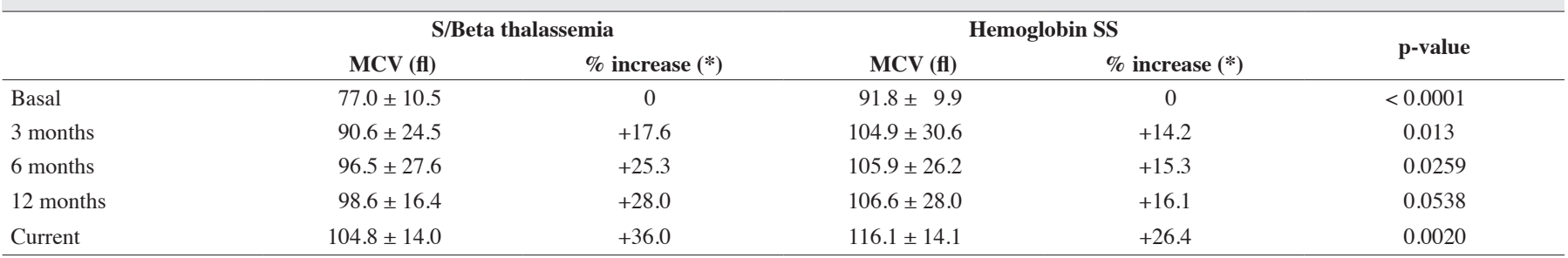

$*$ Percentage increase S/Beta thalassemia vs. SS - p-value $=0.018$

Table 2 - MCH concentrations (mean \pm standard deviation) and changes after hydroxyurea treatment in sickle cell patients

\begin{tabular}{|c|c|c|c|c|c|}
\hline & \multicolumn{2}{|c|}{ S/Beta thalassemia } & \multicolumn{2}{|c|}{ Hemoglobin SS } & \multirow{2}{*}{ p-value } \\
\hline & MCH g/dL & $\%$ change $*$ & MCH g/dL & $\%$ change $*$ & \\
\hline Basal & $32.2 \pm 2.3$ & 0 & $33.2 \pm 2.0$ & 0 & ns \\
\hline 3 months & $31.9 \pm 2.0$ & -0.9 & $33.5 \pm 2.0$ & +0.6 & 0.0168 \\
\hline 6 months & $32.0 \pm 1.8$ & -0.6 & $33.2 \pm 1.8$ & 0 & ns \\
\hline 12 months & $32.2 \pm 1.9$ & 0 & $32.9 \pm 1.6$ & -1.2 & ns \\
\hline Current & $30.7 \pm 1.5$ & -4.6 & $32.1 \pm 1.3$ & -3.6 & 0.0031 \\
\hline
\end{tabular}

*Percentage change S/Beta thalassemia vs. SS - p-value not significant, ns: non-significant 


\section{Discussion}

The hematological and cellular effects of HU treatment are expressed within the first weeks ${ }^{(11)}$ with increases in total $\mathrm{Hb}, \mathrm{Hb}$ $\mathrm{F}, \mathrm{MCH}$ and $\mathrm{MCV}$; in adults however, this is not always persistent during the entire treatment due to exhaustion of erythropoiesis. Once the medication is stopped, the hematological parameters return to the basal level after several months. The observed macrocytosis does not result from a lack of folate or vitamin B12, but from a rearrangement of the cellular protein synthesis. HU is an antimetabolite inhibitor of phase S (synthesis) of the cell cycle. Erythropoiesis occurs under tension due to the action of erythropoietin, which alters production to the fetal phase, producing gamma chains in the most primitive erythroblasts, which, along with alpha chains, produce Fetal $\mathrm{Hb}$. More recently, the role of nitric oxide has been shown in hemoglobin synthesis where the guanosine monophosphate signaling system leads to the activation of the gamma-globulin gene $(\gamma)^{(12,13)}$. The result is an increase in volume and cellular hydration, which reduces the concentration of hemoglobin $\mathrm{S}$. In addition, $\mathrm{S} /$ Beta thalassemia has free alpha chains that conjugate with gamma chains thus producing more $\mathrm{Hb} \mathrm{F}$. According, for some authors, this is one of the reasons that HU treatment is better in S/Beta thalassemia compared to SS patients ${ }^{(4,7,8)}$.

In several studies there are overlapping results for SS and S/Beta thalassemia patients. Data referring only to S/Beta thalassemia are scarce. In 1995 Voskaridou $^{(4)}$ studied 14 S/Beta thalassemia adults who had taken HU for 2 to 3 years. In 4 weeks they had presented great increases of $\mathrm{Hb}$ F, MCV and $\mathrm{MCH}$, but this was lost over the long term. In the present study, as expected, patients presented increases in $\mathrm{Hb} \mathrm{F}$, total $\mathrm{Hb}$ and $\mathrm{MCV}$ in both groups, thus confirming the action of HU (with satisfactory adherence to treatment) in respect to sickle cell disease. Macrocytosis took longer to be expressed in $\mathrm{S} /$ Beta thalassemia due to microcytosis and hypochromia of the thalassemic cell population, which varies according to the beta gene mutation. The values of MCV in S/Beta thalassemia patients increased by $17.6 \%$ in three months, $25.3 \%$ in six months, $28 \%$ in 12 months and $36 \%$ after a mean follow-up of six years ( $p$-value $<0.0001$ in relation to the basal level). The values of MCV in SS individuals increased in the same periods by $14.2 \%$, $15.3 \%, 16.1 \%$ and $26.4 \%$, respectively ( $\mathrm{p}$-value $<0.0001$ ). These results show that the increase in MCV was more intense in $\mathrm{S} /$ Beta thalassemia patients compared to $\mathrm{SS}$ individuals ( $\mathrm{p}$-value $=0.018$ ). The average MCV in S/Beta thalassemia only exceeds $100 \mathrm{fl}$ after a long time (after 12 months), whereas the MCV in SS subjects reaches this value within 3 months (Table 1). There was no significant difference between the groups in respect to the $\mathrm{MCH}$ concentrations (Table 2). Despite the increases in $\mathrm{Hb} \mathrm{F}$ and total $\mathrm{Hb}$, the $\mathrm{MCH}$ concentration did not change significantly. The greater effectiveness of HU in S/Beta thalassemia does not seem to be linked to the lower $\mathrm{MCH}$ concentration, which would mean a lower possibility of polymerization and, consequently sickling. in 1997, Rogers ${ }^{(5)}$, reporting on two children with $\mathrm{S} /$ Beta thalassemia being treated with doses of HU lower than the maximum tolerated, showed that the clinical improvement is similar to SS patients, as is the increase in $\mathrm{Hb} F$ and MCV. Koren $^{(6)}$ studied 19 children and adults but did not separate S/Beta thalassemia and SS patients. The study of Loukopoulos et al. of $55 \mathrm{~S} /$ Beta thalassemia and $14 \mathrm{SS}$ Greeks stratified in SS, S/Beta ${ }^{0}$ thalassemia and $\mathrm{S} / \mathrm{Beta}^{+}$thalassemia Groups, showed increases in the total $\mathrm{Hb}$ and percentage of $\mathrm{Hb} \mathrm{F}^{(7)}$. The authors found, at the end of the study with a maximum dose of $1.5 \mathrm{~g} /$ day HU, increases in total $\mathrm{Hb}$ in the $\mathrm{SS}$ and $\mathrm{S} / \mathrm{Beta}^{0}$ thalassemia Groups, but not in the $\mathrm{S} / \mathrm{Beta}^{+}$thalassemia Group, and increases in the percentage of $\mathrm{Hb} \mathrm{F}$ in all groups ( $\mathrm{p}$-value $<0.001$ ). The data of the current study, without separating $\mathrm{S} / \mathrm{Beta}^{+}$thalassemia and $\mathrm{S} / \mathrm{Beta}^{0}$ thalassemia, demonstrated increases in the total $\mathrm{Hb}$ and $\mathrm{Hb} \mathrm{F}$ in both groups with HU doses similar to the study of Loukopoulos et al.

Loukopoulos et al. also found significant increases in MCV for all groups (26 fl - SS, $28.8 \mathrm{fl}-\mathrm{S} / \mathrm{Beta}^{0}$ thalassemia and $20.8 \mathrm{fl}$ - S/Beta ${ }^{+}$thalassemia). The data of the current study differ from the study of Loukopoulos in respect to the $\mathrm{MCH}$ concentration, as there was a reduction, albeit not significant, in $\mathrm{S} / \mathrm{Beta}^{0}$ thalassemia patients. The explanation might be the different degree of suspension of the beta globin synthesis with mutations present in the Greek ${ }^{(7)}$ (Caucasians) and Brazilian (mixed race) populations. The Brazilian population of S/Beta thalassemia might have benign African mutations ${ }^{(2,14-17)}$ besides the classical Mediterranean ones. In the Mediterranean region, two-thirds of the population with sickle cell disease is composed of $\mathrm{S} /$ Beta thalassemia with severe mutations in contrast to the Brazilian population with an absolute predominance of homozygous S. The study by Rigano ${ }^{(8)}$ of $22 \mathrm{~S} /$ Beta thalassemia individuals showed a significant increase ( $\mathrm{p}$-value $<0.001$ ) in $\mathrm{Hb} \mathrm{F}$ and MCV after HU treatment, which increased from $73.1 \mathrm{fl}$ to 96.4 $\mathrm{fl}(+23.3 \mathrm{fl})$ by the end of the study. No differences were seen in the levels of total $\mathrm{Hb}$ and total leukocytes. This author as well as others ${ }^{(4,7)}$ emphasizes the better effect of HU in S/Beta thalassemia disease. The LaSHS study ${ }^{(9)}$, which focused on survival, did not separate the $\mathrm{SS}$ and $\mathrm{S} /$ Beta thalassemia Groups in respect to $\mathrm{MCV}$, but confirmed the great benefit of the $\mathrm{HU}$ in $295 \mathrm{~S} /$ Beta thalassemia patients, with MCV levels increasing from $54 \%$ to $87 \%\left(\right.$ S/Beta $\left.{ }^{\circ}\right)$ and from $66 \%$ to $82 \%\left(\mathrm{~S} / \mathrm{Beta}^{+}\right)$after 10 years of continuous use. The limitations of the current study were that the mutations, the alpha:beta chain ratio and the presence of alpha thalassemia ${ }^{(18)}$, which may change the globular index were not identified, and other possible causes of macrocytosis, such as bone marrow dysplasia, were not investigated. Moreover, the study population was small, while in the other studies ${ }^{(4,5,7,8)}, 93$ S/Beta thalassemia patients were analyzed.

\section{Conclusion}

Macrocytosis resulting from the action of $\mathrm{HU}$ in $\mathrm{S} /$ Beta thalassemia patients measured by MCV, is lower than that observed in homozygous $\mathrm{S}$ at 6 months of treatment but it reaches a comparative value after more than 1 year. Microcytosis and hypochromia due to the thalassemia mutation contribute to this effect. The $\mathrm{MCH}$ concentration does not reduce significantly, but it is higher in S/Beta thalassemia. These differences must be considered when evaluating adherence to HU treatment and the hematological effects of this drug in S/Beta thalassemia. Multicenter studies with more patients are necessary to accurately evaluate the hematological alterations with HU treatment in the different subtypes of sickle cell disease. 


\section{References}

1. Weatherall DJ, Clegg JB, editors. The thalassemia syndromes. $4^{\text {th }}$ ed. London: Blackwell Science; 2001.

2. Zago MA, Costa FF, Freitas TC, Bottura C. Clinical, hematological and genetic features of sickle-cell anemia and sickle- $\beta$ thalassemia in a Brazilian population. Clin Genet. 1980;18(1):58-64.

3. Charache S, Terrin ML, Moore RD, Dover GJ, Barton FB, Eckert SV, et al. Effect of hydroxyurea on the frequency of painful crises in sickle cell anemia. Investigators of the Multicenter Study of Hydroxyurea in Sickle Cell Anemia. N Engl J Med. 1995;332(20):1317-22. Comment in: N Engl J Med. 1996;334(5):333-4; N Engl J Med. 1995;333(15):1008-9; N Engl J Med. 1995;332(20):1372-4.

4. Voskaridou E, Kalotychou V, Loukopoulos D. Clinical and laboratory effects of long-term administration of hydroxyurea to patients with sickle-cell/beta-thalassaemia. Br J Haematol. 1995; 89(3):479-84.

5. Rogers ZR. Hydroxyurea therapy for diverse pediatric populations with sickle cell disease. Semin Hematol. 1997;34(3 Suppl 3):42-7.

6. Koren A, Segal-Kupershmit D, Zalman L, Levin C, Abu Hana M, Palmor $\mathrm{H}$, et al. Effect of hydroxyurea in sickle cell anemia: a clinical trial in children and teenagers with severe sickle cell anemia and sickle cell beta-thalassemia. Pediatr Hematol Oncol. 1999;16(3):221-32.

7. Loukopoulos D, Voskaridou E, Kalotychou V, Schina M, Loutradi A, Theodoropoulos I. Reduction of the clinical severity of sickle cell/ beta-thalassemia with hydroxyurea: the experience of a single center in Greece. Blood Cells Mol Dis. 2000;26(5):453-66.

8. Rigano P, Rodgers GP, Renda D, Renda MC, Aquino A, Maggio A. Clinical and hematological responses to hydroxyurea in Sicilian patients with $\mathrm{Hb}$ S/Beta thalassemia-thalassemia. Hemoglobin. 2001;25(1):9-17.

9. Voskaridou E, Christoulas D, Bilalis A, Plata E, Varvagiannis K, Stamatopoulos G, et al. The effect of prolonged administration of hydroxyurea on morbidity and mortality in adult patients with sickle cell syndromes: results of a 17-year, single-center trial (LaSHS). Blood. 2010;115(12):2354-63. Comment in: Blood. 2010;115(12):2331-2.

10. Miller MK, Zimmerman SA, Schultz WH, Ware RE. Hydroxyurea therapy for pediatric patients with hemoglobin SC disease. J Pediatr Hematol Oncol. 2001; 23(5):306-8.

11. Ballas SK, McCarthy WF, Guo N, Brugnara C, Kling G, Bauserman RL, et al. Early detection of response to hydroxyurea therapy in patients with sickle cell anemia. Hemoglobin. 2010;34(5): 424-9.

12. Charache S, Dover GJ, Moore RD, Eckert S, Ballas SK, Koshy M, et al. Hydroxyurea: effects on hemoglobin $\mathrm{F}$ production in patients with sickle cell anemia. Blood. 1992;79(10):2555-65. Comment in: Blood. 1992;79(10):2503-6.

13. Saunthararajah Y, Atweh G. Induction of fetal hemoglobin in the treatment of sickle cell disease and $\beta$ thalassemia. In: Steinberg MH, Forget BG, Higgs DR, Weatherall DJ editors. Disorders of hemoglobin genetics, pathophysiology, and clinical management. $2^{\text {nd }}$ ed. Edinburgh: Cambridge University Press; 2009.

14. Silveira ZM. Caracterização molecular e laboratorial da talassemia beta e da interação hemoglobina S/talassemia beta. Rev Bras Hematol Hemoter. 2010;32(5):425-6.

15. Sonati MF, Kaeda J, Kimura EM, Costa FF, Luzzatto L. Mild clinical expression of S-b thalassemia in a Brazilian patient with the $b^{+}$IVS-I-6 (T->C) mutation. Genet Mol Biol. 1998;21(4):1415.

16. Fonseca SF, Kerbauy J, Escrivão C, Figueiredo MS, Cançado R, Arruda VR, et al. Genetic analysis of $\beta$-thalassemia major and $\beta$-thalassemia intermedia in Brazil. Hemoglobin. 1998;22(3):197-207.

17. Zamaro PJ, Bonini-Domingos CR. The identification of beta-thalassemia mutants in Brazilians with high $\mathrm{Hb} F$ levels. Rev Bras Hematol Hemoter. 2010;32(3):215-8 .

18. Wenning MR, Kimura EM, Costa FF, Saad ST, Gervásio S, de Jorge $\mathrm{SB}$, et al. Alpha-Globin genes: thalassemic and structural alterations in a Brazilian population. Braz J Med Biol Res. 2000;33(9):1041-5. 